\title{
Transport of toxic dinoflagellates via ships' ballast water: bioeconomic risk assessment and efficacy of possible ballast water management strategies
}

\author{
Gustaaf M. Hallegraeff * \\ School of Plant Science, University of Tasmania, GPO Box 252-55, Hobart, Tasmania 7001, Australia
}

\begin{abstract}
The results of 10 yr of Australian research efforts on transport of toxic dinoflagellate cysts via ships' ballast water are reviewed, supplemented with the conclusions of similar studies now underway in Europe, Israel, North America, Canada, Japan, China and New Zealand. Toxic dinoflagellates are probably the best studied model organism to assess the bioeconomic risks of ballast water introduction of nonindigenous marine pests. A plausible scenario for their successful introduction and establishment in Australian waters is: (1) ballast water intake during seasonal plankton blooms and to a lesser extent via resuspended cysts in sediments from Japanese or Korean ports; (2) survival as resistant resting cysts during the ballasting process, the voyage in a dark ballast tank, and subsequent ballast water discharge (inoculation); (3) successful germination of cysts, sustained growth and reproduction of plankton cells in an Australian port; and (4) further spreading via coastal currents or domestic shipping, culminating under suitable environmental conditions in harmful algal blooms impacting on aquacultural operations (causative organisms of paralytic shellfish poisoning). Until international agreement and acceptance of a fully effective, practicable, safe, economically viable and environmentally friendly hallast water treatment is achieved (mid-ocean ballast water exchange and heat treatment are the only options offering promise at present), an international warning network for algal blooms in ports appears to be an effective way to minimise risks. It is also recommended that aquaculture operations and marine parks should be sited well clear of the ballast water influence of shipping ports.
\end{abstract}

KEY WORDS: Shıps' ballast water - Toxic dinoflagellate cysts Ballast water treatment Ballast water management

\section{INTRODUCTION}

My interest in the problem of transport of toxic dinoflagellates via ships' ballast water was raised by alarming observations of an apparent global increase in the frequency, intensity and geographic distribution of paralytic shellfish poisoning (PSP) (Anderson 1989, Smayda 1990, Hallegraeff 1993). This human illness (15\% mortality) results from the consumption of shellfish products contaminated with alkaloid toxins from some 11 species of plankton dinoflagellates (Hallegraeff et al. 1995). These species include Alexandrium

•E-mail: hallegraeff@utas.edu.au catenella (Whedon and Kofoid) Balech, A. minutum Halim, A. tamarense (Lebour) Balech, Gymnodinjum catenatum Graham and Pyrodinium bahamense Plate var. compressum (Böhm) Steidinger, Tester et Taylor. While in a ștrict sense this is a completely natural phenomenon well known to native North American Indian tribes, until 1970 poisoning records were confined to temperate waters of Europe, North America and Japan (Hallegraeff 1993). However, by 1990 PSP outbreaks were documented throughout the Southern Hemisphere, including South Africa, Australia, New Zealand and Papua New Guinea and the Northern Hemisphere, including India, Thailand, Brunei, Sabah, and the Philippines (Fig. 1). Similarly, in the Australian 


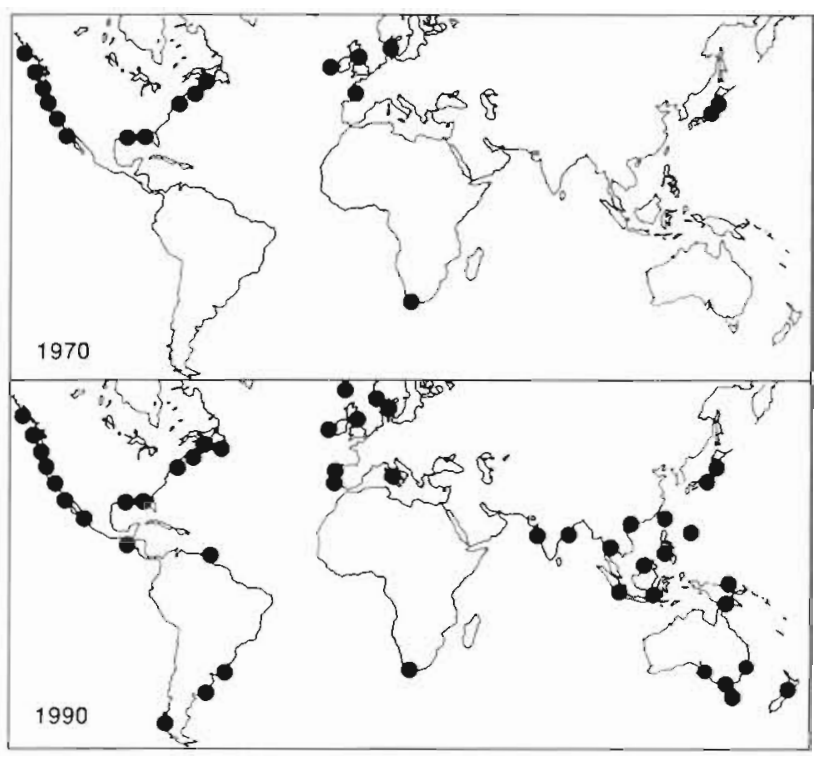

Fig. 1. Apparent global increase in the geographic distribution of paralytic shellfish poisoning (PSP) between 1970 (top) and 1990 (bottom) (after Hallegraeff 1993). Explanations for this incroase include increased scicntifie awarencss, stimulation of dinoflagellate blooms by coastal eutrophication, as well as translocation of species via ships' ballast water

region PSP was unknown until the late 1980 s when the first toxic dinoflagellate blooms appeared in the ports of Hobart (caused by $G$. catenatum), Melbourne (A. catenella) and Adelaide (A. minutum) (Hallegraeff et al. 1988). Explanations for this apparent global increase include increased scientific awareness caused by the developing aquaculture industry and stimulation of dinoflagellate blooms by increased coastal eutrophication, but in a limited number of cases translocation of nonindigenous estuarine dinoflagellate species across oceanic boundaries (either via ships' ballast water or translocation of shellfish products) appears more probable (Hallegraeff \& Bolch 1991).

The extent to which the extensive blending of coastal waters by the transport of seawater ballast has contributed to the apparent 'cosmopolitanism' of many coastal plankton taxa cannot yet be assessed. While unambiguous evidence for the presence of viable toxic dinoflagellate cysts in ships' ballast water (up to 300 million cysts per ballast tank; both Alexandrium and Gymnodium catenatum; Hallegraeff \& Bolch 1992) as well. as associated with shellfish stocks (Scarratt et al. 1993, Rhodes et al. 1994, Honjo et al, 1998) is now available, to prove that a particular dinoflagellate population is nonindigenous is extremely difficult. For $G$. catenatum in Tasmania such evidence has focused on an Australian-wide sediment survey for its distinct fossilisable resting cyst (Bolch \& Hallegraeff 1990, McMinn et al. 1998). Fossil cyst records of this species are absent from the whole Australian region, recent cyst beds are confined to southeast Tasmania, and ${ }^{210} \mathrm{~Pb}$ dated sediment cores from the Hobart region unambiguously demonstrate its sudden appearance around 1972 coinciding with the commencement of bulk woodchip export from southern Tasmania via Japanese cargo vessels (Fig. 2). The precise origin of the Tasmanian dinoflagellate population is still unclear and is currently being traced by means of a global population study of toxin signatures (Oshima et al. 1993), sexual mating compatibility (Blackburn et al. 1989) and RAPD-PCR molecular markers (Adachi et al. 1997, Bolch et al. 1998). Early results indicate that $G$. catenatum populations which recently appeared also on the Australian mainland in Victoria (since 1992; Sonneman \& Hill 1997), South Australia (1996; Bolch \& Hallegraeff unpubl.) and New South Wales (Hallegraeff et al. 1998) are most closely related to the Tasmanian populations (Bolch et al. 1998), which may be the result of recent dispersal of Tasmanian $G$. catenatum via domestic ballast water or domestic translocation of shellfish products. Unfortunately, Alexandrium cysts lack resistant sporopollenin walls and hence do not leave a fossil record. In this latter case, the evidence has focused on a comparison of populationspecific small subunit rRNA sequences which has

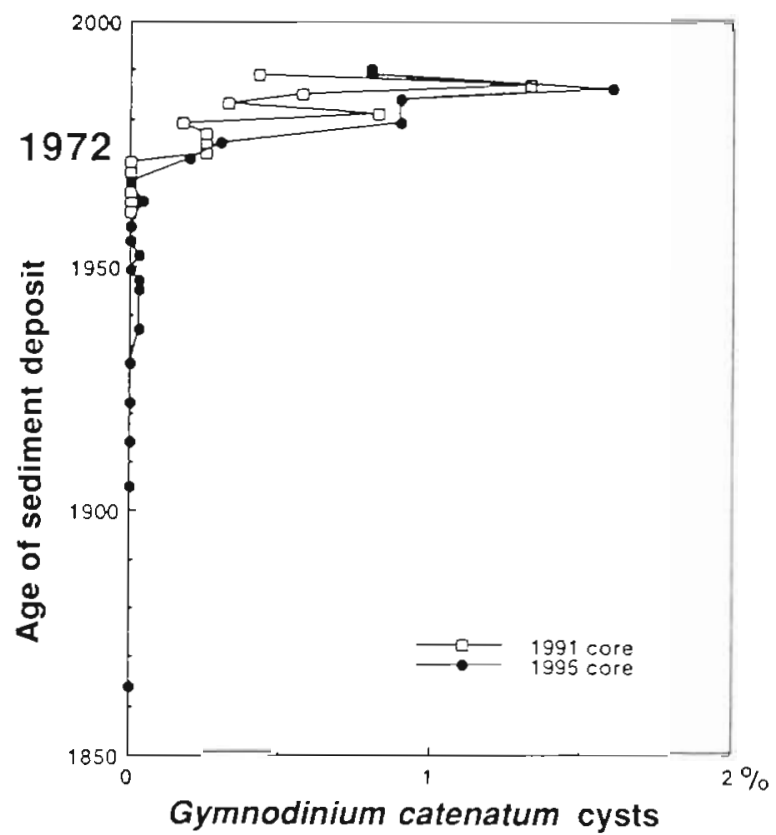

Fig. 2. Micropaleontological evidence for the introduction of the toxic dinoflagellate Gymnodinium catenatum into southern Tasmanian waters. Depth distribution of cysts (as \% of total dinoflagellate cysts) in 2 undisturbed $40 \mathrm{~cm}$ deep sediment cores demonstrate the sudden appearance of this species around 1972 coincident with the opening of a woodchip mill. Sediment dating is based on ${ }^{210} \mathrm{~Pb}$ and ${ }^{137} \mathrm{Cs}$ radıonuclide analyses (from McMinn et al. 1998) 
revealed a remarkable match between Japanese and Australian A. catenella, and between European and Australian A. minutum (Fig. 3; Scholin et al. 1995) while at the same time $A$. catenella and $A$. minutum strains from neighbouring New Zealand exhibit unique ribotype signatures (C. Scholin pers. comm.). The problem with such molecular evidence is that because of the slow rate of evolution of rDNA and our current inability to date the 'molecular clock', we cannot yet confidently distinguish whether matching molecular fingerprints are the results of thousands of years of natural dispersal along coastlines or anthropogenic translocations within the last $50 \mathrm{yr}$. The possibility that Alexandrium cells and cysts in sediment cores can leave diagnostic biochemical markers such as sterols is being explored as a further line of evidence (compare Hallegraeff et al. 1991).

In conclusion, while the scientific evidence on the magnitude of the problem of toxic dinoflagellate dispersal via ships' ballast water is not yet complete, the risk of ballast water introductions by this and a wide range of other marine organisms (Carlton 1985, Carlton \& Geller 1993) has been amply demonstrated and the 'not doing anything' option is no longer acceptable. The Australian Government's position (Jones 1991) has been to classify ballast water as a quarantine problem and to attempt 'minimising quarantine risks' rather than to aim for the near impossible task of complete elimination of the risks from introduced species. In this context, cyst-producing toxic dinoflagellates have proved to be useful model-organisms, based on the premise that any monitoring strategy or ballast water treatment technique capable of dealing with them most likely would also eliminate most of the other target species. In Australia, other target species include the bacterium Vibrio cholerae, seaweed Undaria pinnatifida, starfish Asterias amurensis, crab Carcinus maenas, and fan worm Sabella spallanzanii. This review summarises 10 yr of Australian research efforts on toxic dinoflagellate cysts in ballast water, supplemented by similar studies now underway in Europe, Israel, North America, Canada, Japan, China and New Zealand.

\section{SCENARIO OF SUCCESSFUL BALLAST WATER INTRODUCTION}

The scenario for a successful ballast water introduction comprises up to 8 separate steps (Fig. 4), which for convenience of discussion will be grouped below into 4 broad categories:

(1) Ballast water intake during seasonal plankton blooms in a donor port. In Australia, $85 \%$ of ballast water imports (a total 120 million tonnes per year) derive from the Asian region, of which $54 \%$ originate in Japanese ports, with a further 34 million $t$ of ballast water transported in association with coastal shipping around Australia (Kerr 1994). Global figures for ballast

Fig 3. Global map summarizing known distributions of different ribotypes of the toxic dinoflagellate species complex Alexandrium tamarense. Using SSU (small subunit) rDNA sequences, evidence could be obtained that Japan has been on the receiving end of introductions from Europe $(E)$, the east and west coast of North America (A), as well as possessing its own indigenous temperate Asian populations (Japan, J; Korea, K). Some of these Japanese, Korean and American rDNA-types were ganned from cultures germinated from ballast water transported from Japan/Korea to Australia. At the same time, indigenous tropical Asian (S), Tasmanian (T) and New Zealand (Z) ribotypes not known from any other region in the world also exist (modified after Scholin et al. 1995!

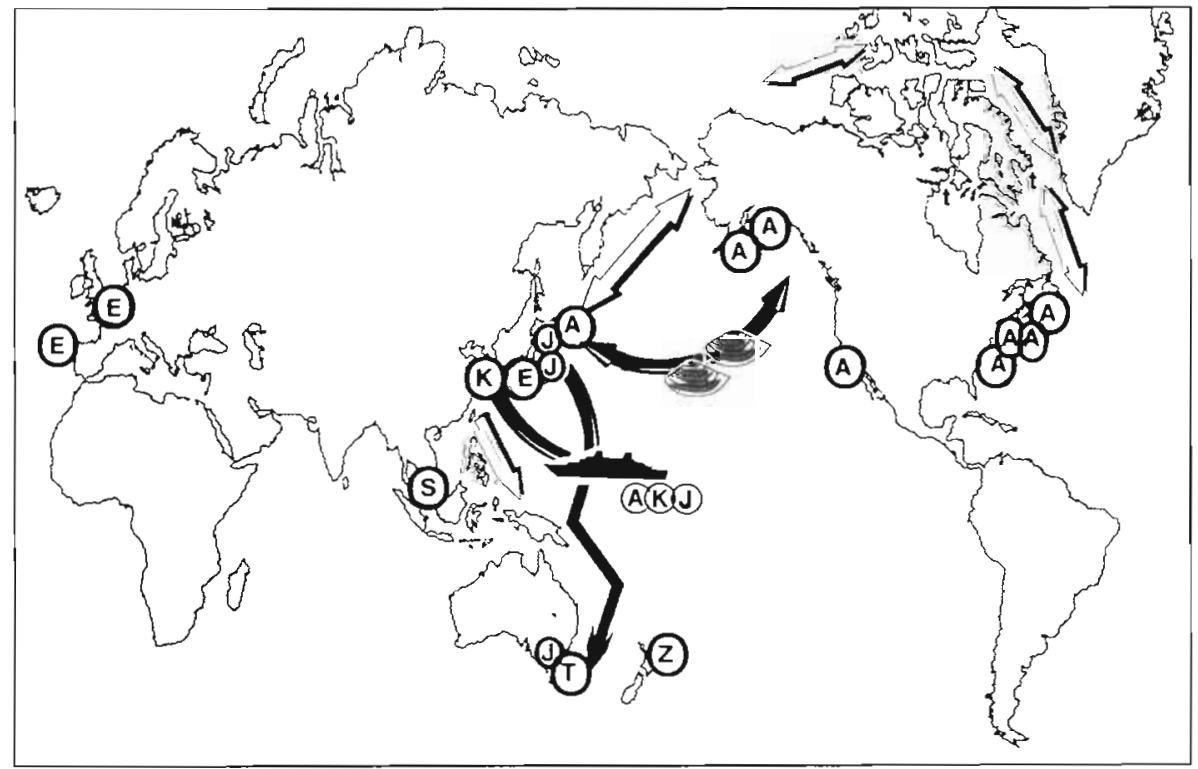

Alexandrium 'tamarense' ribotypes A North American

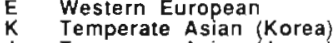
Temperate Asian (Korea) Tropical Asian Tropical Asian New Zealand
Dispersal Vectors

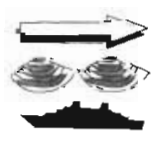

paleo-currents

translocation of shellfish

ship ballast water 


\section{Presence of Organism in Port}

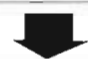

\begin{tabular}{|c|}
\hline Uptake in Ship's Ballast Water \\
\hline Survives Ballast Uptake \\
\hline Survives voyage in Ballast Tank \\
\hline Survives De-Ballasting \\
\hline Survives in New Environment \\
\hline Organism is able to Reproduce and \\
become Established in New Environment \\
\hline \\
\hline
\end{tabular}

Fig. 4. Flow chart summarising the steps necessary for the successful introduction of a marine organism via ships' ballast water. Monitoring of ballast water would be most effective if carried out at the overseas port, before or during ballast water uptake. Ballast water treatment would be most effective if carried out while the ship is in transit

water transport are as high as 10 billion $\mathrm{t} \mathrm{yr}^{-1}$ (Carlton \& Geller 1993) Toxic PSP dinoflagellates occur widespread in Japanese coastal waters: Alexandrium tamarense is found mainly in Northern Japan, A. catenella is found mainly in Southern Japan, while Gymnodinium catenatum occurs in the Seto Inland Sea and Yatsushiro Sea (Fukuyo 1985, Matsuoka \& Fukuyo 1994; Fig. 5). A. tamarense was first recognised in Korean waters in 1986 (Park 1991), and our identification of $G$. catenatum cysts in Korean ballast water samples represented a new record of this species for that region (Hallegraeff \& Bolch 1992), which was subsequently confirmed by cyst surveys in Chinhae Bay (Kim et al. 1995). The probability of ballast water intake of toxic dinoflagellates is strongly dependent upon shipping patterns, seasonality of plankton blooms in ballasting port waters and the presence of local sediment cyst beds. In both Japanese and Korean coastal waters, toxic dinoflagellate blooms tend to occur mainly in early spring to summer (March to June) and again in fall (September to November) (Ogata et al. 1982, Fukuyo 1985). However, bloom events vary con-

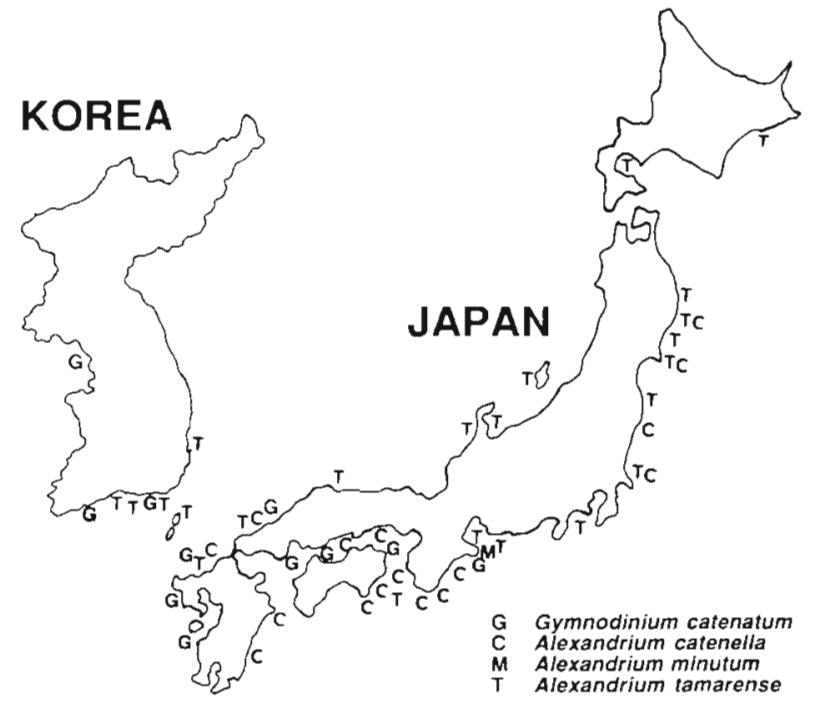

Fig. 5. Knnwn distribution of PSP dinoflagellates in Japanese and Korean ports, which represent the major donor regions for Australian ballast water introductions (based on Fukuyo 1985. Matsuoka \& Fukuyo 1994). An international warning network for algal blooms in ports appears to be an effective wav to minimise risks

siderably in magnitude from year to year, dependent upon water temperature and rainfall. In a survey of 343 cargo vessels, Hallegraeff \& Bolch (1992) found that $65 \%$ of ships contained ballast tank sediments. Of the sediment-containing samples, $50 \%$ contained dinoflagellate cysts and 5\% contained toxic dinoflagellate cysts. Significantly, of the 80 known extant dinoflagellate cyst species, 53 taxa were detected in ballast tank samples and 20 species were successfully germinated to produce viable cultures (Hallegraeff \& Bolch 1992). Toxic dinoflagellate cysts of $A$. catenella, $A$. tamarense and $G$. catenatum were positively identified in these Australian ballast water surveys. Similarly, Macdonald \& Davidson (1997) detected Alexandrium cysts (including $A$. minutum and A. tamarense) in $17 \%$ of ships arriving in Scottish ports after short voyages through regional European seas. Tropical Pyrodinium bahamense dinoflagellate cysts have not yet been detected in ballast water samples, but the vegetative cells of this species have been found in New Zealand ballast water monitoring (Hay et al. 1997). Of further concern is the possible ballast water dispersal of cyst stages of the potent toxic dinoflagellate Pfiesteria piscicida Steidinger et Burkholder (Burkholder et al. 1998), only known thus far from North Carolina and the Chesapeake Bay areas of North America. The seasonality of ships arriving in Australian ports testing positive for toxic dinoflagellate cysts closely reflects the seasonality of overseas plankton blooms (Fig. 6). Cyst dormancy requirements indicate that most ballast water cysts derive from plankton blooms in the water column 

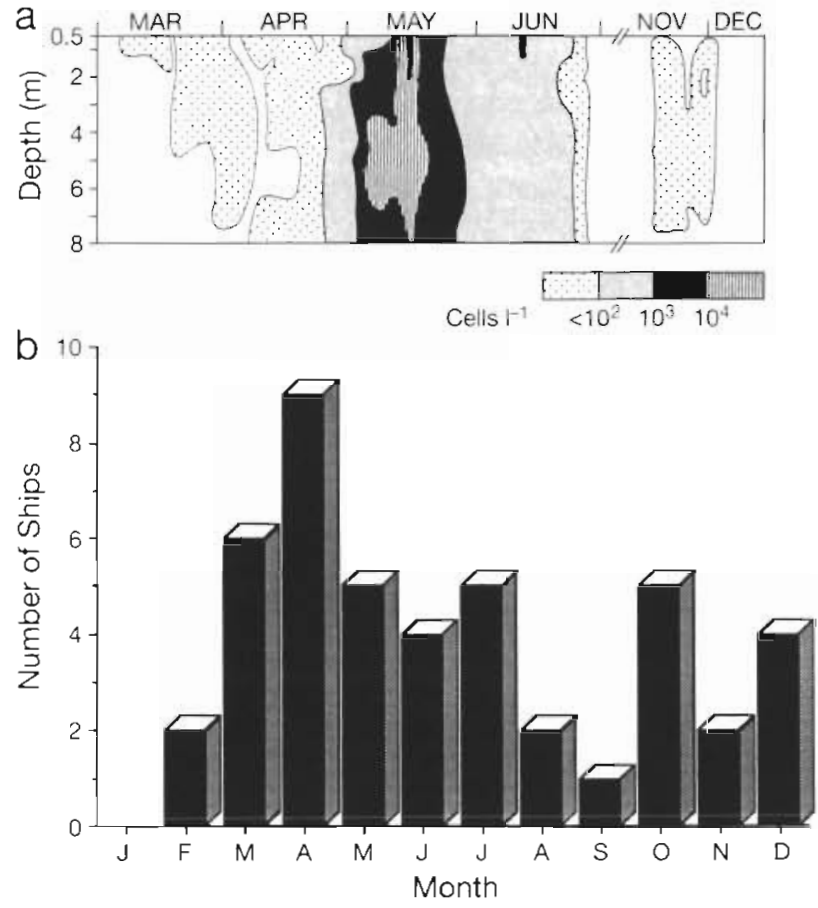

Fig. 6. (a) The seasonal occurrence of toxic dinoflagellate blooms (Alexandrium) in Japanese coastal waters (after Ogata et al. 1982) is reflected in (b) the seasonal occurrence of toxic dinoflagellate cysts in ship ballast water samples, intercepted at 18 different Australian ports during 1987 to 1995 (based on data from Hallegraeff \& Bolch 1992 and Australian Government Analytical Laboratories (AGAT) unnubl data)

(estimated $90 \%$ of ships). Some cysts failed to germinate until about 6 mo later, suggesting that they were newly formed cysts undergoing a mandatory dormancy period (Anderson 1980), rather than mature cysts resuspended from harbour sediments. Oshima et al. (1992) traced a toxic dinoflagellate bloom from Muroran in Japan (40000 cells $\mathrm{l}^{-1}$; July 1989) to Eden in Australia, by matching up toxin fingerprints of Japanese dinoflagellate plankton, of ballast water cysts and of the germinated dinoflagellate cultures. In a limited number of cases, ships originating from, for example, Kure in Japan were found to carry toxic dinoflagellate cysts throughout the year which suggests that resuspended sediment cysts can be an additional source for contaminated ballast water (estimated $10 \%$ of ships) or that material entrained in ballast tanks can be retained for several voyages.

(2) Survival as resistant resting cysts during the ballasting process, the voyage in a dark ballast tank, and subsequent ballast water discharge. Examination of ballast water samples from ships arriving in 18 Australian ports (Hallegraeff \& Bolch 1992) as well as routine ballast water inspections made en-route during 3 voyages on the 'Iron Whyalla' (Rigby \& Hallegraeff 1994, Rigby et al. 1997) have shown that motile, photo- synthetic dinoflagellate cells usually do not survive long voyages in ballast tanks where massive phytoplankton mortalities are incurred 1 to $3 \mathrm{~d}$ after ballasting. Many dinoflagellate cells are sensitive, first to the turbulence imposed during ballast pumping (Thomas \& Gibson 1990), followed by unfavourable conditions in ballast tanks of darkness, changing temperature and nutrient conditions, as well as increased vulnerability to zooplankton grazing The only motile dinoflagellate species that tend to survive are members of mixotrophic and heterotrophic genera such as Protoperidinium, Phalacroma and Diplopsalopsis which primarily feed on detritus (see also Galil \& Hülsman 1997). Such on-board or end-of-voyage phytoplankton ballast tank observations are now available for ships travelling between Japan and Australia (Rigby \& Hallegraeff 1994, Yoshida et al. 1996), Japan and North America (Kelly 1993), Japan and Canada (Rigby \& Hallegraeff 1994. Yoshida et al. 1996) and voyages within Europe (Macdonald \& Davidson 1998). Unfortunately, numerous phytoplankton ballast tank surveys exclusively utilised preserved samples (e.g. Subba Rao et al. 1994, Zhang 1997) and hence were unable to determine whether species were being discharged in a viable condition. Overall, the major risk is posed by the resistant cyst stages (hypnozygotes) of dinoflagellates, such as Alexandrium catenella, A. minutum, A. tamarense and Gymnodinium catenatum (Fig. 7). No cyst mortality can be expected to result from the ballasting process itself, and during the voyage grazing by zooplankton will not affect survival as the persistent cysts survive passage through the animals' guts and can be excreted in a viable form within their fecal pellets (Scarratt et al. 1993). Mortality would occur, however, if the cysts were to germinate and find themselves in the wrong environmental conditions. G. catenatum cysts, once produced in the plankton and unless inhibited by anoxic conditions in sediments, will usually germinate within $2 \mathrm{wk}$ after formation (Blackburn et al. 1989) and thus could suffer major mortality. In contrast, Alexandrium cysts, newly formed in the plankton, require a mandatory dormancy period of 1 up to 6 mo (Anderson 1980, Anderson et al. 1987) and hence are not exposed to this risk. Mature Gymnodinium or Alexandrium cysts, buried in harbour sediments where they are prevented from germination by anoxic conditions, would probably try to germinate when resuspended during ship ballast water intake. Rapid burial within ballast tank sediments would enhance their further survival during the voyage.

(3) Successful germination of cysts, sustained growth and reproduction of plankton cells in an Australian port. For toxic dinoflagellates, which tend to occur in comparatively high concentrations, the volume of ballast water transported is not necessarily the best risk 

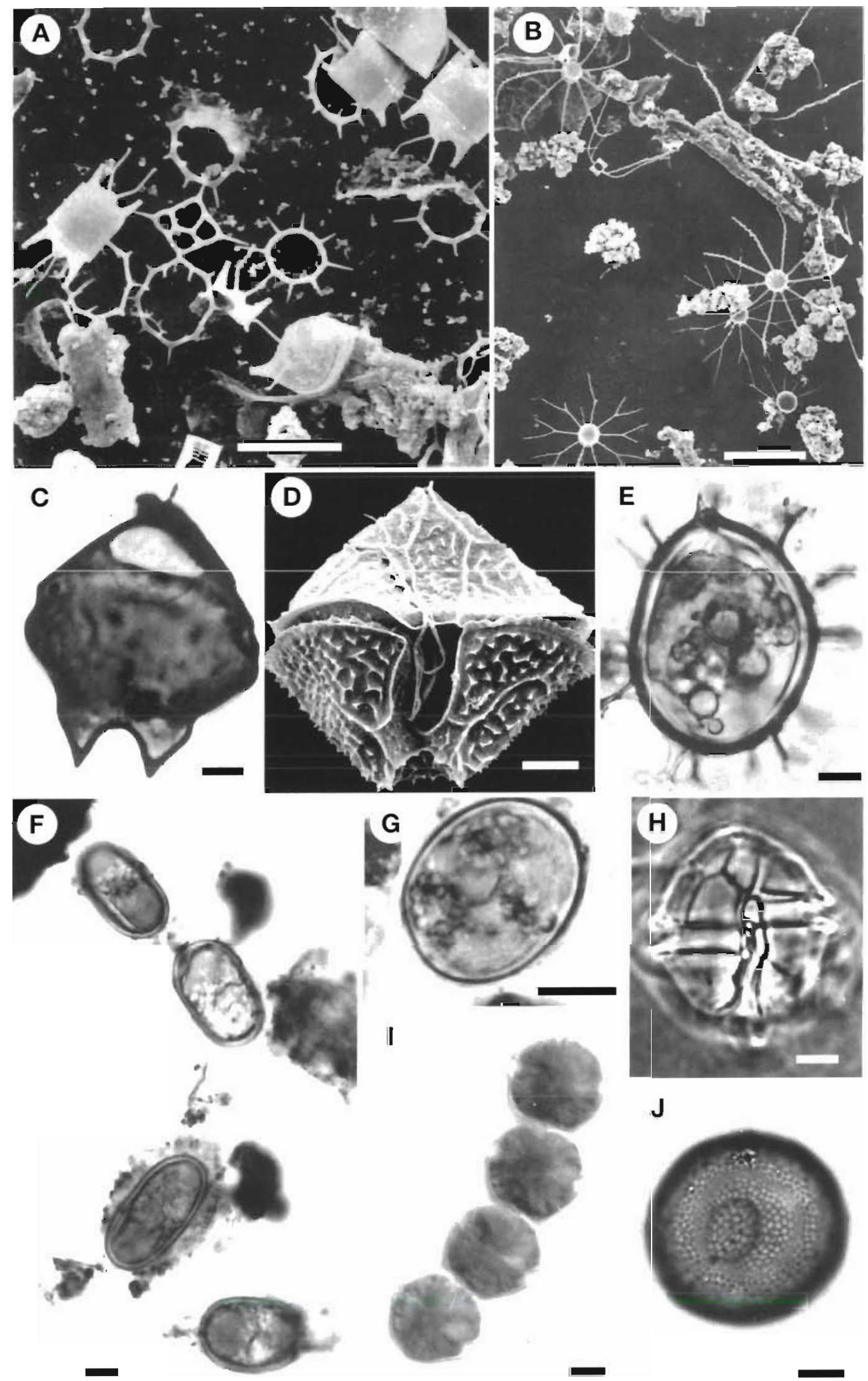
Fig. 7. Representative micrographs of diatom plankton cells and dinoflagellate resting cysts from ballast water samples arriving in Australian ports. SEM = scanning electron micrograph; LM = light micrograph. (A) SEM. Diatom Odontella aurita and silicoflagellate Dictyocha speculum from a woodchip vessel arriving in Triabunna, Tasmania, from Yatsushiro, Japan. (B) SEM. Warmwater diatom Bacteriastrum furcatum from a woodchip vessel arriving in Triabunna from Yura, Japan. (C) LM. Dinoflagellate cyst of Protoperidinium leonis from a vessel arriving in Triabunna from Yatsushiro, Japan. (D) SEM. Ventral view of motile dinoflagellate cell germinated from the cyst shown in C. (E) LM. Live dinoflagellate cyst of Gonyaulax digitale showing cell contents, from a vessel arriving in Port Hedland from Pohang, Korea. (F) Live toxic dinoflagellate cysts of Alexandrium tamarense from a vessel arriving in Eden from Muroran, Japan. (G) LM. Live toxic dinoflagellate cyst of $A$. catenella from a vessel arriving in Port Hedland from Kashima, Japan. (H) LM. Motile toxic dinoflagellate cell of A. tamarense cultured from the cysts in F. (I) Motile toxic dinoflagellate chain of A. catenella cultured from the cyst in G. (J) round, brown toxic dinoflagellate cyst of Gymnodinium catenatum with microreticulate ornamentation and horse-shoe shaped apical groove; from a vessel arriving in Newcastle from Kohong, South Korea (after Hallegraeff \& Bolch 1992). All scale bars $=10 \mu \mathrm{m}$

indicator. A viable inoculum could consist of as little as a single cell, and frequency of ships' visits (Fig. 8) therefore more adequately reflects the risk of repeated ballast water discharges during different seasons. During 1991, the Australian Port Hedland received 407 visits, Hay Point 403, Newcastle 500, Sydney 171 and Hobart 26 (Kerr 1994). Ballast water movements are most significant to the first 3 ports, but the climate match of ships entering the tropical ports of Port Hedland (17\% match) and Hay Point $(4 \%)$ is poor. In contrast, Newcastle $(90 \%$ of ships coming from similar climates), Sydney (56\%) and to lesser extent Hobart (85\% match, but limited traffic) are exposed to more significant risks (Rigby \& Hallegraeff 1996). Fig. 9a summarises Australian ports where toxic dinoflagellates have been detected in ship ballast water samples.
During and after the deballasting process in the Australian port, the cyst stages may be readily buried below the sediment surface from which they are gradually resuspended into the water column. These cysts may undergo recurrent germination attempts over the next 10 to $20 \mathrm{yr}$. When successful, this can result in dinoflagellate blooms in the Australian port. Once the organism produces new cyst stages, it will have effectively colonised a new water body from which it cannot be eradicated. Accepting the sediment cyst evidence that indicates that $G$. catenatum was introduced into Tasmania around 1972 (McMinn et al. 1998), it took another $8 \mathrm{yr}$ for the first bloom events to develop in the new environment in 1980 (Hallegraeff et al. 1988). While the 'most damage has already been done' attitude is prevalent among many developed countries,

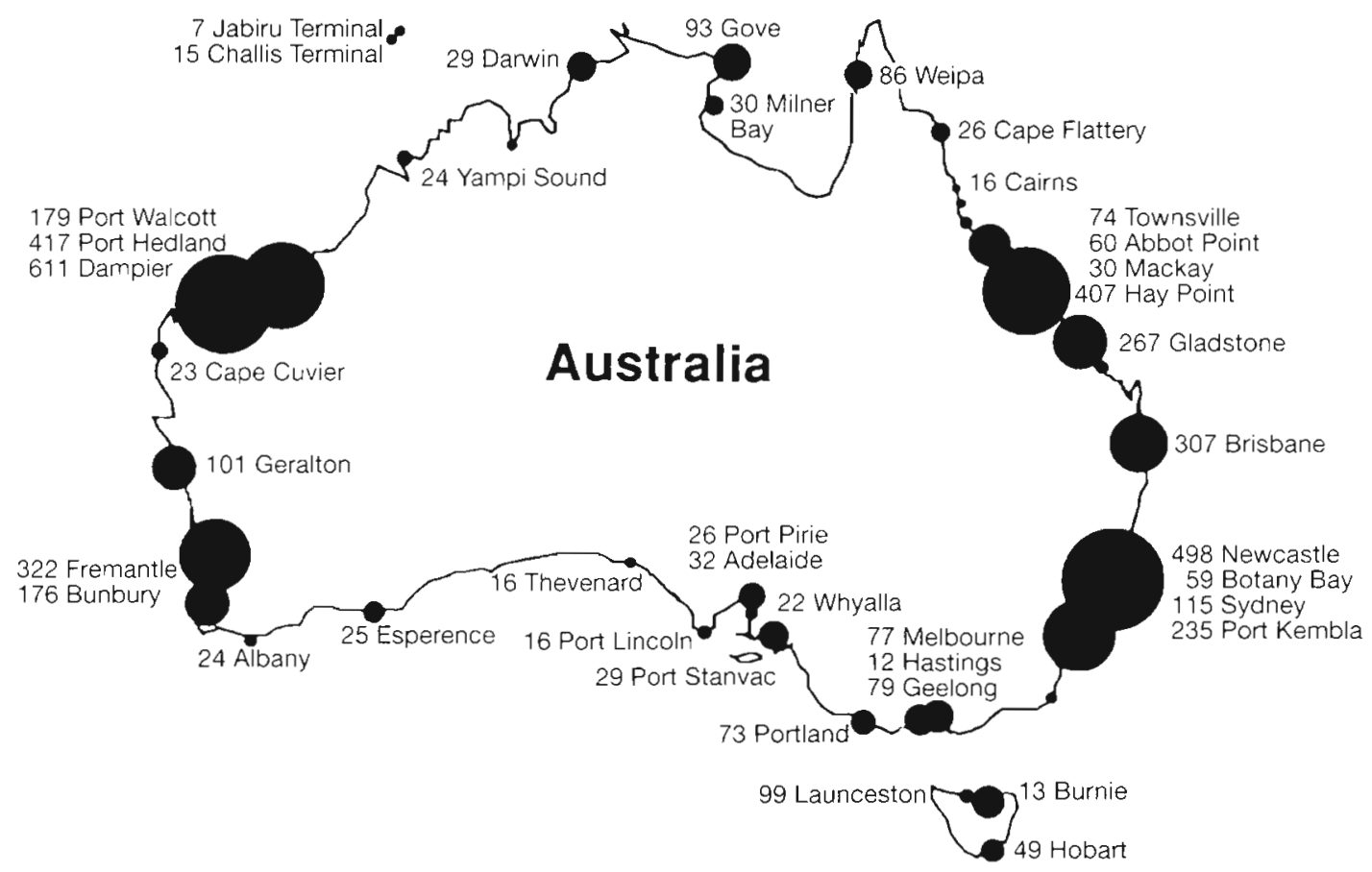

Fig. 8. Frequency of ship visits during 1991 to Australian ports receiving ballast water from bulk carriers (from Kerr 1994) 

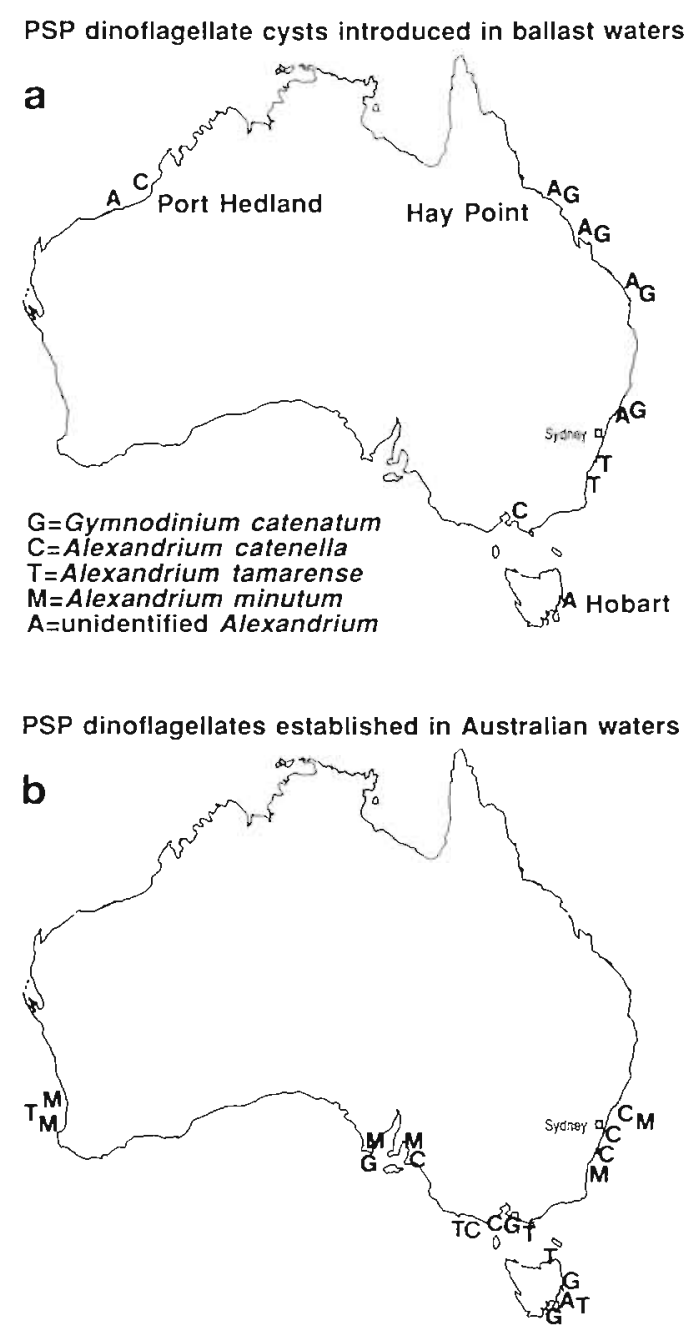

Fig. 9. Illustration of the importance of matching of donor port and receiving port environments. (a) Toxic dinoflagellate cysts detected in ballast water from ships entering Australian ports during 1987 to 1995 (based on Hallegraeff \& Bolch 1992). (b) Australian ports where toxic dinoflagellate populations, both indigenous and introduced strains, have become established (based on Hallegraeff et al. 1988, 1991, McMinn et al. 1998, Hallegraeff \& Bolch unpubl.)

evidence is accumulating that numerous damaging ballast water invasions (e.g. European zebra mussel into Laurentian Great Lakes; Japanese starfish and Undaria pinnatifida seaweed into Tasmania; American Atlantic coast comb jelly into the Black Sea) did not occur until the early 1980s. This suggests that the ballast water problem is increasing, in response to increasing global ballast water movements but also perhaps to environmental factors such as coastal pollution enhancing the invasibility of receiving ports (Carlton \& Geller 1993, and references therein).

(4) Further spreading via coastal currents or domestic shipping, culminating under suitable environmental conditions in harmful algal blooms impacting on aquacultural operations. Estuarine dinoflagellates are sensitive to water temperature, to lesser extent salinity, and often show associations with river plumes and rainfall events (contributing micronutrients and/or chelating humic substances; Hallegraeff et al. 1995, Wells et al. 1991). The most meaningful approach to estimate the probability that introduced dinoflagellates can establish themselves in Australian ports would be to look at dinoflagellate cyst assemblages in various Australian ports with particular attention to the presence of species which in other parts of the world are associated with Alexandrium or Gymnodinium catenatum. A further approach would be to compare seasonal temperature and tidal current/water column stability regimes in Australian and overseas ports. Of interest is the absence of toxic dinoflagellate populations in the Australian Ports of Hay Point and Port Hedland (Fig. 9b). despite the fact that cyst species of $G$. catenatum and Alexandrium have been repeatedly detected in ballast water samples discharged in these areas. In contrast, the port of Hobart which has insignificant shipping traffic has a disproportionally high number of introduced species [dinofiageiiate $\bar{G}$. catenatum, but aiso seaweed Undaria pinnatifida (Sanderson 1990) and starfish Asterias amurensis (Byrne et al. 1997)]. This illustrates the importance of matching port environments in the successful establishment of introduced species. Domestic transport of ballast water obviously poses a much greater risk for translocation of organisms than international shipping. Domestic transport of viable Alexandrium and Dinophysis dinoflagellate populations has been documented by Gosselin et al. (1995) for short $(<36 \mathrm{~h})$ voyages in the Gulf of St Lawrence region. Macdonald \& Davidson (1998) detected Dinophysis and Pseudo-nitzschia (toxigenic diatom genus) in 11 and $37 \%$ of ships, respectively, arriving in Scottish ports but their viability was not confirmed. Even though the diatom Pseudo-nitzschia does not produce resting spores, this organism is able to survive conditions of darkness in some form of physiological resting stage. Viable cultures of Pseudo-nitzschia species have been obtained from ballast tanks sampled at the end of domestic Australian voyages as well as international Japanese voyages (E. Forbes \& G. Hallegraeff unpubl.). The toxigenic diatom species $P$. multiseries was positively identified from preserved ballast water arriving in Hong Kong (Zhang 1997).

\section{BALLAST WATER MANAGEMENT}

Until we achieve international acceptance of a fully effective, safe, practicable, financially viable and environmentally friendly ballast water treatment option, risk minimisation is the only option. A monitoring net- 
that have accumulated on the bottom of ballast tanks (Hallegraeff \& Bolch 1992). Currently, there exist no appropriate methods for monitoring the efficacy of ballast water exchange protocols and verification of compliance by the shipping industry largely relies on inspection of ship log books. Useful biological indicators in this respect are the incidence of coastal versus oceanic, and coldwater versus warm-water phytoplankton species (Fig. 7a, b), while the presence of abundant viable phytoplankton in ballast tanks tends to reflect recent ocean exchange (Hallegraeff \& Bolch 1992, Hay et al. 1997. Macdonald \& Davidson 1998).

Most forms of chemical treatment (e.g. chlorine) would lead to unacceptable environmental problems in the port waters in which they eventually would be discharged. Chemical treatment with hydrogen peroxide $(5000 \mathrm{ppm}$ required to kill Alexandrium catenella or Gymnodium catenatum cysts; Bolch \& Hallegraeff 1993) which would degrade to innocuous water and oxygen has also been ruled out as a treatment option since it would be prohibitively expensive (A\$500000 per ship per trip; Rigby et al. 1993). Similarly, electric shock treatment, envisaged to be appiied to bailast water outlets (Montani et al. 1995), has been discarded as a treatment option once it became clear that it is not electricity but local generation of heat and/or free chlorine that was responsible for mortality observed in laboratory experiments (Hallegraeff et al. 1997). Efforts to kill ballast water organisms by deoxygenation of ballast tanks (e.g. Mountfort 1997) would not kill dinoflagellate cysts nor many benthic marine invertebrates, while research to apply high speed microfiltration to ballast water (Cangelosi 1997) may not be successful for dinoflagellates or their cysts because of limitations imposed by the 50 and $100 \mu \mathrm{m}$ screens used (trials with $20 \mu \mathrm{m}$ screens suffer from rapid clogging) Ozonation and ultraviolet treatment have also proved unsuccessful in killing dinoflagellate cysts when these were contained in turbid ballast water with high organic loading (D. Oemcke pers. comm., J. Valentine unpubl.).

In contrast, heating of ballast water may provide an effective, environmentally friendly solution to the global problem of ballast water transport of unwanted marine organisms. If practicable, it would involve a once-only cost in terms of modifying ship engineering designs, would indiscriminately eliminate a wide range of marine organisms (without the need for monitoring of target organisms in ballast water), and would not pose any environmental hazards as associated with chemical treatment, nor create any ship's safety hazards as posed by mid-ocean ballast water exchange (Rigby et al. 1993). This approach to ballast water treatment is analogous to pasteurization of milk (30 min at $65^{\circ} \mathrm{C}$ ) and other food products, in that it aims to kill cer- tain unwanted pathogenic organisms but it is not synonymous with sterilisation (typically 15 min at $121^{\circ} \mathrm{C}$ ) since not all organisms (i.e. bacterial endospores) can be expected to be killed. Crucial questions remain to be answered, however, as to the amount of heat that can be generated on board ship (Rigby \& Taylor 1993). In laboratory studies, toxic dinoflagellates cysts could be killed after $2 \mathrm{~h}$ at $35^{\circ} \mathrm{C}$ (Gymnodium catenatum) or $4.5 \mathrm{~h}$ at $38^{\circ} \mathrm{C}$ (Alexandrium catenella) (Hallegraeff et al. 1997). While early studies (Bolch \& Hallegraeff 1993 ) employed short exposures (30 to $90 \mathrm{~s}$ ) to temperatures of 40 to $45^{\circ} \mathrm{C}$, it has now become clear that longer exposures (hours to days) to temperatures of 36 to $38^{\circ} \mathrm{C}$ is more effective, especially for killing zooplankton (Rigby et al. 1997). A careful assessment of various waste heat sources on the BHP bulk carrier 'Iron Whyalla' has confirmed the practicability of this approach, and a pilot heat treatment plant was successfully trialled on-board ship in April 1997, achieving temperatures of 37 to $38.4^{\circ} \mathrm{C}$ after 24 to $30 \mathrm{~h}$ (Rigby et al. 1997). Early indications are that other ballast water target organisms, such as the starfish Asterias amurensis (bipinnaria iarvae die at $>28^{\circ} \mathrm{C}$; Suiton \& Bruct 1996), seaweed Undaria pinnatifida (gametophyte dies at $>25^{\circ} \mathrm{C}$, sporophyte $>30^{\circ} \mathrm{C}$; Sanderson 1990) and the mollusc Dreissena polymorpha ( 2 h at 33 to $36^{\circ} \mathrm{C}$ Jenner \& Janssen-Mommen 1993) can also be killed in this temperature range, but not, for example, the pathogenic bacterium Vibrio cholerae (McCarthy \& Khambaty 1994). The precise physiological mechanism underlying the effectiveness of this comparatively mild heat treatment is not completely understood, but mortality most likely is due to a loss of cellular organisation rather than simple protein inactivation or disruption of membrane integrity (Brock \& Madigan 1994). Concerns that such mild heating of ballast tank seawater could stimulate the growth of pathogenic bacteria such as $V$. cholerae have not been substantiated by simulated laboratory culture experiments (Desmarchelier \& Wong 1996).

(3) Upon arrival at the receiving Australian port, and before commencement of deballasting. The routine monitoring of toxic dinoflagellate cysts in ships' ballast water and sediments is hampered by the lack of a sensitive, rapid diagnostic test which can be used by untrained personnel. Until we achieve international agreement on a suitable ballast water treatment option, an international warning network for algal blooms in overseas ports appears to be an effective way to minimise risks. It is also recommended that aquaculture operations and marine parks should be sited well clear from the ballast water influence of shipping ports. For too long, the shipping industry has had a virtually free ride on the world's oceans with grave environmental consequences for our precious 
coastal environments. Bulk cargo shipping ought to be subject to strict regulations, analogous to the limitations that apply to coastal or aquaculture developments.

The increasing interest in the ballast water problem is reflected in the establishment in 1997 of a joint study group on Ballast Water and Sediments by the International Council for the Exploration of the Sea (ICES), the Intergovernmental Oceanographic Commission (IOC) of UNESCO, and the International Maritime Organisation (IMO). In 1995, Australia created a new Centre for Research on Introduced Marine Pests (CRIMP) under the auspices of the Commonwealth Scientific and Industrial Research Organisation (CSIRO). Finally, the Australian Quarantine and Inspection Service (AQIS) currently chairs the Marine Environment Protection Committee (MEPC) of the International Maritime Organisation, in which Australia has proposed and argued for international regulations of ballast water control (partly based on voluntary guidelines introduced into Australia in February 1990) to be drafted as Annex VII to the MARPOL 73/78 Convention (International Convention for Preventing Pollution from Ships). IMO (resolution A.868) has now endorsed for such an Annex on mandatory ballast water guidelines to be implemented in the year 2000. The significance of this development is that ships arriving in any port of the signatory member countries would then need to demonstrate that they have done at least something to minimise the risk of ballast water transport of nonindigenous marine organisms, whether it be evidence of mid-ocean exchange, heat treatment or by presenting a certificate of freedom from harmful organisms in the port of origin. The scientific and political challenges to solve the global environmental problem of ballast water introductions compare with the magnitude of the problems faced when addressing global climate change. It is hoped that this ballast water review, focusing on toxic dinoflagellate cysts as a model organism, will contribute to clarifying the bioeconomic risk factors involved and to identifying possible management strategies.

Acknowledgements. This review was first presented at the 'Theme Session on Ballast. Water' of the ICES Conference held in Aalborg, Denmark, in September 1995, while a later version was presented at the International Phycological Congress in Leiden, The Netherlands (August 1997) and at a meeting of the Royal Society of Tasmania (October 1997). The International Oceanographic Commission (IOC) kindly funded my attendance at the ICES conference. Mr Chris Bolch (now at University of Tasmania) assisted in the early stages of the routine dinoflagellate cyst monitoring (1987-1990), which was subsequently continued by Mr Neil Blain and Mr Dean Clarke of the Australian Government Analytical Laboratories (AGAL, Melbourne). I have benefitted from valuable collaboration with Dr Geoff Rigby and
Mr Alan Taylor (BHP Research Laboratories) who taught me about shipping operations. I am grateful to Dr Meryl Williams (previously at Burtau of Resource Sciences) and Mr Denis Paterson (A.ustralian Quarantine and Inspection Service) for instructing me in the art of government policies, and to Dr Ron Thresher and Dr Chad Hewitt (CRIMP) for discussions on invasion biology. My views on ballast water issues have evolved while an active member (1989 until present) of the Research Advisory Group (RAG) of the Australian Ballast Water Management Advisory Council (ABWMAC). This work was supported by grants from the Fishing Industry Research and Development Council and through consultancy contracts with BHP and AQIS.

\section{LITERATURE CITED}

Adachi M, Sako X, Ishida Y (1997) Analysis of Gymnodinium catenatum Dinophyceae using sequences of the $5.8 \mathrm{~S}$ rDNA-ITS regions and random amplified polymorphic DNA. Fish Sci 63:701-707

Anderson DM (1980) Effects of temperature conditioning on development and germination of Gonyaulax tamarensis (Dinophyceae) hypnozygotes. J Phycol 16:166-172

Anderson DM (1989) Toxic algal blooms and red tides: a global perspective. In: Okaichi $T$, Anderson. $D$, Nemoto $T$ (eds) Red tides: biology, environmental science and toxicology. Elsevier, New York, p 11-16

Anderson DM. Taylor CD, Armbrust V (1987) The effects of darkness and anaerobiosis on cyst germination. Limnol Oceanogr 32:340-351

Blackburn SI, Hallegraeff GM. Bolch CJ (1989) Vegetative reproduction and sexual life cycle of the toxic dinoflagellate Gymnodinium catenatum from Tasmania, Australia. J Phycol 25:577-590

Bolch CJ, Blackburn SI, Hallegraeff GM, Vaillancourt RE (1998) Molecular genetic variation among different global populations of the toxic dinoflagellate Gymnodinium catenatum revealed by RAPD-PCR. Proc 8th lnt Conf Harmful Algae, Vigo, p 283-286

Bolch CJ, Hallegraeff GM (1990) Dinoflagellate cysts in recent marine sediments from Tasmania, Australia. Bot Mar 33:173-192

Bolch CJ. Hallegraeff GM (1993) Chemical and physical options to kill toxic dinoflagellate cysts in ships' ballast water. J Mar Environ Engineering 1:23-29

Brock TD, Madigan MT (1994) Biology of microorganisms, 6 th edn. Prentice Hall

Burkholder JM, Glasgow HB, Lewitus A.J, Tester PA. (1998) Physiological ecology of Ptinsteria piscicida, with general comments on 'ambush-predator' dinoflagellates. In: Anderson DM, Cembella AD, Hallegraeff GM (eds) Physiological ecology of harmful algal blooms, NATO-ASI Series 41. Springer-Verlag, Heldelberg, p 175-192

Byrne M, Morrice MG, Wolf B (1997) Introduction of the northern Pacific asteroid Asterias amurensis to Tasmania: reproduction and current distribution. Mar Biol 127: $673-685$

Cangelosi A (1997) The Algonorth experiment. Seaway Review 25, no. 3, January-March 1997

Carlton JT (1985) Transoceanic and interoceanic dispersal of coastal marine organisms: the biology of ballast water. Oceanogr Mar Biol Annu Rev 23:313-374

Carlton JT, Geller JB (1993) Ecological roulette: the global transport and invasion of nonindigenous marine organisms. Science 261:78-82 
Desmarchelier P. Wong F (1996) The potential for Vibrio cholerae to translocate and establish in Australian waters. Consultancy report for Australian Quarantine and Inspection Service, Ballast Water Research Project no. 5, Australian Government Publishing Service, Canberra

Fukuyo Y (1985) Morphology of Protogonyalax tamarensis (Lebour) Taylor and Protogonyaulax catenella (Whedon and Kofoid) Taylor from Japanese coastal waters. Bull Mar Sci 37:529-537

Galil BS, Huilsmann N (1997) Protıst transport via ballast water-biological classification of ballast tanks by food web interactions. Eur J Protistol 33:244-253

Gosselin S, Levasseur M, Gauthier D (1995) Transport and deballasting of toxic dinoflagellates via ships in the Grande Entree Lagoon of the Iles-de-la-Madeleine (Gulf of St Lawrence, Canada). In: Lassus P et al. (eds) Harmful marine algal blooms. Lavoisier Publ Inc, Paris, p 591-596

Hallegraeff GM (1993) Review of harmful algal blooms and their apparent global increase. Phycologia 32:79-99

Hallegraeff GM. Anderson DM, Cembell.a A.D (eds) (1995) Manual on harmful marine microalgae. IOC manuals and guides no. 33, UNESCO, Paris

Hallegraeff GM, Bolch CJ (1991) Transport of toxic dinoflagellate cysts via ships' ballast water. Mar Pollut Bull 22: $27-30$

Hallegraeff GM, Bolch CJ (1992) Transport of dinoflagellate cysts in ship's ballast water: implications for plankton biogeography and aquaculture. J Plankton Res 14: $1067-1084$

Hallegraeff GM, Bolch CJ, Blackburn SI, Oshima Y (1991) Species of the toxigenic dinoflagellate genus Alexandrium in south-eastern Australian waters. Bot Mar 34:575-587

Hallegraeff GM, Hardiman S, Church AG (1998) Recent dinoflagellate cysts of the lower Hawkesbury River Estuary. NSW, Australia. Technical Report, Environmental. Protection Authority, Chatswood, NSW (in press)

Hallegraeff GM, MCCausland MA, Brown RK (1995) Early warning of toxic dinoflagellate blooms of Gymnodinium catenatum in southern Tasmanian waters. J Plankton Res $17: 11.63-1176$

Hallegraeff GM, Nichols PD, Volkman JK, Blackburn SI, Everitt DA (1991) Pigments, fatty acids, and sterols of the toxic dinoflagellate Gymnodinium catenatum. J Phycol 27: $591-599$

Hallegraeff GM, Steffensen DA, Wetherbee R (1988) Three estuarine Australian dinoflagellates that can produce paralytic shellfish toxins. J Plankton Res 10:533-541

Hallegraeff GM, Valentine JP, Marshall JM, Bolch CJ (1997) Temperature tolerances of toxic dinoflagellate cysts: application to the treatment of ships ballast water. Aquat Ecol 31:47-52

Hay C, Handley S, Dodgshun T, Taylor M, Gibbs W (1997) Cawthron's ballast water research. Final report. Cawthron Institute Report 417, Nelson, New Zealand

Hayes KR (1997) A review of ecological risk assessment methodologies. Centre for Research on Introduced Marine Pests, Technical Report no.13, CSIRO, Hobart

Honjo T, Imada N, Oshima Y, Maema Y, Nagai K, Matsuyamas $Y$, Uchida T (1998) Potential for the inadvertent transfer of detrimental dinoflagellate Heterocapsa circularisquama with consignments of pear oysters between aquaculture sites. Proc 8th Int Conf Harmful Algae, Vigo, p) $224-226$

Ichlkawa S, Wakao Y, Fukuyo Y (1992) Extermination efficacy of hydrogen peroxide against cysts of red tide and toxic dinoflirellates, and its adaptability to ballast water of cargo sh.jps. vippon Suisan Gakkashi 58:2229-2233
Jenner HA, Janssen-Mommen JPM (1993) Monitoring and control of Dreissena polymorpha and other macrofouling bivalves in the Netherlands. In: Nalepa TF; Schloesser PW (eds) Zebra mussels: brology, impacts and control. Lewis Publishers, Boca Raton, FL, p 537-554

Jones MM (1991) Marine organisms transported in ballast water: a review of the Australian scientific position. Bureau of Rural Resources Bulletin no. 11. Australian Government Publishing Service, Canberra

Kelly JM (1993) Ballast water and sediments as mechanisms for unwanted species introductions into Washington state. J Shellfish Res 12:405-410

Kerr SB (1994) Ballast water-ports and shipping study, Australian Quarantine and Inspection Service, Ballast Water Research Series, report no. 5. Australian Government Publishing Service, Canberra

Kim HG, Matsuoka K, Lee SG (1995) New findings of a toxic dinoflagellate Gymnodinium catenatum from Chinhae Bay, Korea. Abstracts 7 th Int Conf Toxic Phytoplankton, Sendai, Japan, p 33

Macdonald EM, Davidson RD (1998) The occurrence of harm$f_{1 t l}$ algae in ballast discharges to Scotush ports and the effects of mid-water exchange in regional seas. Proc 8th Int Conf Harmful Algae, Vigo, p 220-223

Matsuoka K. Fukuyo Y (1994) Geographical distrıbution of the toxic dinoflagellate Gymnodinium catenatum Graham in Japanese coastal waters Rnt Mar 37.495-503

McCarthy SA, Khambaty FM (1994) International dissemination of epidemic Vibrio cholera by cargo ship ballast water and other nonpolable waters. Appl Environ Microbiol 60: $2597-2601$

McMinn A, Hallegraeff GM, Thomson P, Jenkinson AV, Heijnis $H(1998)$ Cyst and radionucleotide evidence for the recent introduction of the toxic dinoflagellate Gymnodinium catenatum into Tasmanian waters. Mar Ecol Prog Ser 161:165-172

Montani S, Meksumpun S, Ichimi K (1995) Chemical and physical treatments for destruction of phytoflagellate cysts. J Mar Biotechnol 2:179-181

Mountfort DO (1997) Ballast water treatment. Cawthron initiates a long-term solution to the ballast water problem. Seafood New Zealand, July 1987, p 38-39

Ogata T, Kodama M, Fukuyo Y, Inoue T, Kamiya H, Matsuura F. Sekiguchi K, Watanabe S (1982) The occurrence of Protogonyaulax spp. in Ofunato Bay, in association with the toxification of the scallop Patinopecten yessoensis. Bull Jpn Soc Sci Fish 48:563-566

Oshima Y, Blackburn SI, Hallegraeff GM (1993) Comparative study on paralytic shellfish toxin profiles of the dinoflagellate Gymnodinium catenatum from three different countries. Mar Biol. 116:471-476

Oshima Y, Bolch CJ, Hailegraeff GM (1992) Toxin composition of resting cysts of Alexandrium tamarense (Dinophyceae). Toxicon 30:1539-1544

Park JS (1991) Red tide occurrence and countermeasure in Korea. In: Park JS, Kim HG (eds) Proc of Korean-French Seminar on Red Tides, held at National Fisheries Research and Development Agency. 9-10 Nov 1990, Korea, p 1-24

Rhodes LL, MacKenzie AL White DA, Smith P (1994) Movement of mussel spat within New Zealand: the risks of associated toxic microalgal introductions. First Int Conf Molluscan Shellfish Safety, Sydney, p 33 (Abstract)

Rigby GR, Hallegraeff GM (1994) The transfer and control of harmful marine organisms in shipping ballast waterbehaviour of marine plankton and ballast water exchange trials on the MV 'Iron Whyalla'. J Mar Environ Engineering $1: 91-110$ 
Rigby GR, Hallegraeff GM (1996) Ballast water controls to minimize the translocation and establishment of toxic phytoplankton: What progress have we made and where are we going? In: Yasumoto T, Oshima Y, Fukuyo Y (eds) Harmful and toxic algal blooms. Int Oceanogr Comm UNESCO, Paris, p 201-204

Rıgby G, Hallegraeff GM, Sutton C (1997) Ballast water heating and sampling trials on the BHP ship MV Iron Whyalla in Port Kembla and en-route to Port Hedland. Report for Australian Quarantine and Inspection Service. October 1997, Canberra

Rigby GR, Steverson IG, Bolch CJ, Hallegraeff GM (1993) The transfer and treatment of shipping ballast waters to reduce the dispersal of toxic marine dinoflagellates. In: Smayda TJ, Shimizu Y (eds) Toxic phytoplankton blooms in the sea. Elsevier, Amsterdam, p 169-176

Rigby GR, Taylor A (1993) Shipping ballast water: heating as a means of destroying potentially harmful marine organisms. BHP Research Technical Note, BHPR/ENV/TN/93/ 005, Newcastle

Sanderson JC (1990) A preliminary survey of the distribution of the introduced macroalga Undaria pinnatifida (Harvey) Suringer on the East Coast of Tasmania, Australia. Bot Mar 33:153-157

Scarratt AM, Scarratt DJ, Scarratt MC (1993) Survival of live Alexandrium tamarense cells in mussel and scallop spat under simulated conditions. J Shellfish Res 12:383-388

Scholin CA, Hallegraeff GM, Anderson DM (1995) Molecular evolution of the Alexandrium tamarense 'species complex' (Dinophyceae): dispersal in the North Amencan and West Pacific regions. Phycologia 34:472-485

Scholin CA, Wainwright N, Hallegraeff GM (1996) Feasibility of developing a rapid diagnostic test for toxic dinoflagellates in shins' ballast water. Consultancy Australian Ouarantine and Inspection Service. Ballast Water Research

Editorial responsibility: Otto Kinne (Editor), Oldendorf/Luhe, Germany
Series, report no. 8, Australian Government Publishing Service, Canberra

Smayda TJ (1990) Novel and nuisance phytoplankton blooms in the sea: evidence for a global epidemic. In: Granéli E et al. (eds) Toxic marine phytoplankton. Elsevier, Now York, p $29-40$

Sonneman JA, Hill DRA (1997) A taxonomic survey of cystproducing dinoflagellates from recent sediments of Victorian coastal waters, Australia. Bot Mar 40:149-178

Subba Rao DV, Sprules WG, Locke A, Carlton JT (1994) Exotic phytoplankton from ships' ballast waters: risk of potential spread to mariculture sites on Canada's East Coast. Can Data Rep Fish Aquat Sci 937.51 p

Sutton CA, Bruce BD (1996) Temperature and salinity tolerances of the larvae of the Northern Pacific seastar Asterias amurensis. Centre for Rusearch on Introduced Marine Pests, Tech Report no. 6, CSIRO, Hobart

Thomas WH, Gibson CH (1990) Effect of small-scale turbulence on microalgae. J Appl Phycol 2:71-77

Yamaguchi M, Itakura S, Imai I, Ishida Y (1995) A rapid and precise technique for enumeration of resting cysts of Alexandrium spp. (Dinophyceae) in natural sediments. Phycologia 34:207-214

Yoshida M, Fukuyo Y. Murase T, Ikegama T (1996) On-board observations of phytoplankton viability in ship's ballast tanks under critical light and temperature conditions. In: Yasumoto T, Oshima Y, Fukuyo Y (eds) Harmful and toxic algal blooms. IOC, Paris, p 205-208

Wells ML, Mayer LM, Guillard RRL (1991) Evaluation of iron as a triggering factor for red tide blooms. Mar Ecol Prog Ser 69:93-102

Zhang F (1997) Harmful algae trom container ship ballast water taken from the open ocean and from Oakland, California (May 1996 to April 1997) MPhil thesis, University of Hong Kong

Submitted: January 5, 1998; Accepted: April 30, 1998 Proofs received from author(s): June 22, 1998 